\title{
Monosodium Glutamate Plus Artemether-lumefantrine Overdose Altered Malondialdehyde, Total Protein and Albumin Concentration in Rats
}

Egbuonu Anthony-Cemaluk C*, Obi Emmanuel, Nwuke Chinedu P, Simon Cynthia Uchechi, Oleghibe Justina Utodinachi, Ezenwafor Nnaemeka Raymond, Chukwu Ebere Mercy Department of Biochemistry, College of Natural Sciences, Michael Okpara University of Agriculture Umudike

\section{* Corresponding Author email: tonycemalukegbuonu@yahoo.com}

Article History

Received: 21 October 2019

Revised: 26 November 2019

Accepted: 01 December 2019

Published: 07 December 2019

\section{Student(s)}

- Obi Emmanuel

- Simon, Cynthia Uchechi

- Oleghibe Justina Utodinachi

- Ezenwafor Nnaemeka Raymond

- Chukwu Ebere Mercy

Academic Year: 2016-17 (2 ${ }^{\text {nd }}$ Semester)
Course Level: Bachelor
Course Name: B.Sc.
Course year: $4^{\text {th }}$ Year $/ 8^{\text {th }}$ Semester

Mentar(s)

- Egbuonu Anthony-Cemaluk C

- $\quad$ Nwuke Chinedu Paulinus

\section{Introduction}

The addition of monosodium glutamate (MSG), to mimic the natural flavour of the non-essential amino acid, glutamate, to most commercially processed foods could be extensive with possible threat to public health [1-6]. Health hazards of MSG could result to oxidative stress in animals [3,7-13]. And, oxidative

Copyright (C) 2019. The Author(s). Published by AIJR Publisher.

This is an open access article under Creative Commons Attribution-NonCommercial 4.0 International (CC BY-NC 4.0) license, which permits any non-commercial use, distribution, adaptation, and reproduction in any medium, as long as the original work is
This study aimed at assessing alterations in malondialdehyde, MDA, total protein and albumin concentration in the serum and liver homogenate of monosodium glutamate (MSG)-challenged rats co-treated with artemether-lumefantrine, AL. Methods involving colourimetric estimation were employed in thirty rats randomly grouped into six $(n=5)$ and for seven consecutive days, fed feed and water (Group A), AL therapeutic dose (Group B), AL overdose (therapeutic dose $\times 5$ ) (Group C), MSG $(8000 \mathrm{mg} / \mathrm{kg}$ body weight) (Group D), AL therapeutic dose plus MSG (Group E) or AL overdose plus MSG (Group F). Total protein concentration $(2.64 \pm 0.09 \mathrm{~g} / \mathrm{dL}, 2.81 \pm 0.14 \mathrm{~g} / \mathrm{dL}$, respectively) in the liver homogenate of rats exposed to MSG (group D) or MSG plus AL overdose (group F) and malondialdehyde concentration in the liver homogenate of MSG plus AL overdose-fed rats $(0.45 \pm 0.04 \mathrm{mg} / \mathrm{ml})$ lowered $(\mathrm{P}<0.05)$ as against other groups. However, serum albumin concentration in MSG $(2.59 \pm 0.13 \mathrm{~g} / \mathrm{dl})$ or AL overdose plus MSG (3.24 $\pm 0.12 \mathrm{~g} / \mathrm{dl})$ fed rats was higher $(\mathrm{P}<0.05)$ compared to the control $(2.02 \pm 0.04 \mathrm{~g} / \mathrm{dl})$. The Total protein: Albumin ratio lowered while the Albumin: total protein ratio increased in rats in MSG, AL overdose plus MSG or AL overdose groups compared with the control. Thus, the apparent MSG plus AL overdose-induced adverse influence on the studied parameters and samples of non-malarial infested rats could be via compromised liver-mediated protein metabolism capacity and biofunctions following possibly enhanced protein-malondialdehyde adduct formation in the rats.

Keywords: Artemesinin-based, therapeutic dose, liver homogenate, malondialdehyde, albumin, total protein 
stress has been implicated in the pathogenesis of diverse diseases, including malaria that is endemic in poor areas [14-16]. Artemisinin-based combination therapies (ACTs) serve as first line anti-malarial in drug resistant malaria parasite which is endemic in sub-Saharan African countries [17-18]. Artemetherlumefantrine, a common artemesisnin-based combination therapy, acts by generating free radicals (prooxidants) and reactive oxygen species that kill the malaria parasites [19-21] but with potential threat to many cells [13, 20-21].

The possible interaction of MSG with artemether-lumefantrine could exert significant influence on the oxidative stress parameters related to protein metabolism of animals, notably in the liver that detoxifies xenobiotics [23] aside metabolizing protein [24]. Oxidative stress was implicated in many diseased conditions $[25,26]$ while abnormal protein metabolism could also result in animal health dysfunctions. Metabolic abnormalities could be detected in the associated bio-indicators in the serum and in high metabolic organs (including liver) homogenate. Furthermore, a possibility of abuse of AL exists as selfmedication with anti-malarial drugs has been reported [27]. Also, possibility of co-intake of artemetherlumefantrine with overdose of monosodium glutamate-flavour enhanced fast foods in absence of malaria infection exists. Recently, in a similar study, Obi and Egbuonu [28] reported a significantly compromised liver morphology and antioxidant capacity.

Notwithstanding the foregoing, there is paucity in literature as regards possible effect on the concentration of malondialdehyde, protein and albumin in the serum and liver homogenate following intake of AL either alone or in combination with intoxicating dose of MSG, warranting the present investigation. Altered liver bio-function could be detrimental to balanced physio-function. In particular, as a good bio-indicator of liver function, protein metabolism function and oxidative stress, malondialdehyde, one of the most abundant aldehyde products of lipid peroxidation, could react on cellular and tissue proteins to form adducts resulting to the alteration of protein function and attendant cellular responses [29]. And albumin, the most abundant blood protein produced in the liver that is important in regulating blood volume and in acting as carrier of non-enzymatic antioxidants including vitamin C, vitamin E and Glutathione serves as a good indicator of liver function and non-enzymatic antioxidant status.

\section{Materials and Methods}

The artemether-lumefantrine $(20: 120 \mathrm{mg})$ was purchased from a medical representative while monosodium glutamate $(99 \%$ purity) was purchased from a foodstuff market, in Umuaha Abia State, Nigeria. A total of thirty (30) male Wistar rats (89-183 g) were kept in the animal house of the Department of Biochemistry, Michael Okpara University of Agriculture, Umudike, Abia State, Nigeria for 14-day to acclimatize. Thereafter, the rats were randomly grouped into six $(6)(\mathrm{n}=$ five rats) and respectively allowed free access to feed and portable water. With a gavage, rats in the control group (Group A) were exposed to distilled water while those in Group B were exposed to AL therapeutic dose. Rats in Group C were exposed to AL overdose, calculated as therapeutic dose for $70 \mathrm{~kg}$ man multiplied by 5, while those in Group D were exposed to MSG. Rats in Group E were exposed to AL therapeutic dose plus MSG whereas those in Group F were exposed to AL overdose plus MSG. The artemether-lumefantrine administration was twice each day at $8 \mathrm{hrs}$ interval [30]. Rats' intoxication with MSG was achieved at $8000 \mathrm{mg} / \mathrm{kg}$ body weight and by daily exposure for 7 days [7,31-34].

All rats used in this study were housed at $25^{\circ} \mathrm{C}$ in stainless steel cages under normal daylight/day cycle. The rats were conditioned throughout the process according to the guidelines approved by the college cum departmental committee on animal use, Michael Okpara University of Agriculture, Umudike on handling of experimental rats. After 7 days, following overnight fast, the rats were sacrificed by ocular puncture. The blood sample of the respective rats was collected into a clean non-anticoagulated polystyrene tube, allowed to clot and centrifuged at $3000 \mathrm{rpm}$ for 5 minutes. The resultant respective serum collected was separately refrigerated until used. The liver of the respective rat was excised, rinsed in iced-cold sucrose, and a $10 \%$ $\mathrm{w} / \mathrm{v}$ homogenate was prepared from it using $0.15 \mathrm{M} \mathrm{KCl}$ as buffer to obtain the supernatant sample after centrifugation [32]. 
Total protein content in the rats' serum and liver homogenate was determined using Peterson's modifications of the Micro-Lowry method with a protein assay kit (Sigma Diagnostics, P 5656, Sigma, MO, USA) based on Buiret method. The absorbance of the sample $\left(\mathrm{A}_{\text {sample }}\right)$ and of the standard $\left(\mathrm{A}_{\text {standard }}\right)$ against the reagent blank was read at $546 \mathrm{~nm}$. The MDA concentration in the rats' serum and liver homogenate was determined by the method of Wallin et al. [35] based on the principles as described in Egbuonu and Ezeanyika [36] that malondialdehyde, MDA, resulting from lipid degradation reacts with thiobarbituric acid to form a red or pink coloured complex which in acid solution absorbs maximally at $532 \mathrm{~nm}$. The absorbance was therefore taken at wavelength $532 \mathrm{~nm}$ and $600 \mathrm{~nm}$ against a blank and the MDA concentration calculated as the percentage thiobarbituric acid reacting substances (TBARS) using the relation:

$$
\% \text { TBARS }=\frac{A_{532}-A_{600} \times 100}{0.571 \times 0.1}(\mathrm{mg} / \mathrm{ml})
$$

Albumin concentration in the rats' serum and liver homogenate was estimated using Bromocresol green (BCG) according to Doumas et al. [37] as reported recently [38]. In brief, this method was based on the principle that under acidic conditions, serum albumin binds specifically and quantitatively with the indicator 3,3,5,5,-tetrabromo-m-cresolsulphonephthelein (bromocresol green, BCG) to form a green coloured albumin-BCG complex that absorbs maximally at $578 \mathrm{~nm}$, the absorbance being directly proportional to the concentration of albumin in the sample, and was measured colourimetrically at $640 \mathrm{~nm}$. The albumin concentration in the sample was calculated from the following formula:

$$
\text { Albumin Concentration }\left(\mathrm{g} / \mathrm{l} \text { or g/dl) }=\frac{A_{\text {sample }}}{A_{\text {standard }}} \times\right. \text { Concentration of standard }
$$

Diagnostic ratios (Total protein:Albumin and Albumin:total protein) in serum and liver homogenate of rats were calculated from the result of this study. The change relative to group was calculated using the relation:

$$
\text { Change relative to } K(\%)=(V-K) / K \times 100
$$

where $\mathrm{K}$ is the constant group value and $\mathrm{V}$ is the variable group values [11,12,25, 31-34, 39-43]. The data were subjected to one-way analysis of variance (ANOVA) using Statistical package for social sciences (SPSS) version 20.0. Results were expressed as mean \pm standard error of mean (SEM). Difference was significant at $\mathrm{p}<0.05$ and by a relative change of ten (10) per cent and above [42].

\section{Results}

As shown in Table 1 , the total protein concentration $(\mathrm{g} / \mathrm{dL})$ in the serum of rats exposed to AL therapeutic dose $(3.62 \pm 0.22 \mathrm{~g} / \mathrm{dl},-22.15 \%$ relative to control), AL overdose $(3.33 \pm 0.07 \mathrm{~g} / \mathrm{dl},-28.39 \%$ relative to control) and intoxicating dose of MSG $(3.72 \pm 0.08 \mathrm{~g} / \mathrm{dl},-20.00 \%$ relative to control) respectively decreased $(\mathrm{P}<0.05)$ as compared to control $(4.65 \pm 0.09 \mathrm{~g} / \mathrm{dl})$. However, the decrease and increase respectively in the total protein concentration of rats' serum concomitantly exposed to AL therapeutic dose and intoxicating dose of MSG $(4.29 \pm 0.05 \mathrm{~g} / \mathrm{dl},-7.74 \%$ relative to control) and AL overdose together with intoxicating dose of MSG $(4.70 \pm 0.18 \mathrm{~g} / \mathrm{dl},+1.08 \%$ relative to control) was not significant $(\mathrm{P}>0.05)$.

Table 1: Total protein concentration $(\mathrm{g} / \mathrm{dL})$ in the serum of normal and monosodium glutamate-intoxicated rats co-treated with artemether-lumefantrine

\begin{tabular}{|c|c|c|c|}
\hline Group & $\begin{array}{c}\text { Total } \\
\text { protein(g/dl) }\end{array}$ & $\begin{array}{c}\text { Changes relative to the } \\
\text { control }(\%)\end{array}$ & $\begin{array}{c}\text { Changes relative to the } \\
\text { MSG group }(\%)\end{array}$ \\
\hline A: Control (feed + water only) & $4.65 \pm 0.09$ & 0.00 & +25.00 \\
\hline B: AL therapeutic dose & $3.62 \pm 0.22$ & -22.15 & -2.69 \\
\hline C: AL overdose & $3.33 \pm 0.07$ & -28.39 & -10.48 \\
\hline D: MSG (8000mgkg ${ }^{-1}$ bwt) & $3.72 \pm 0.08$ & -20.00 & 0.00 \\
\hline E: AL therapeutic dose + MSG & $4.29 \pm 0.05$ & -7.74 & +15.32 \\
\hline F: AL overdose + MSG & $4.70 \pm 0.18$ & +1.08 & +26.34 \\
\hline
\end{tabular}

Values are mean \pm SEM for $n=5 .+$ denotes higher by; - denotes lower by. Difference considered statistically significant at $p<0.05$ and a relative change of ten (10) per cent and above [42]. 
Monosodium Glutamate Plus Artemether-lumefantrine Overdose Altered Malondialdebyde, Total Protein and Albumin Concentration in Rats

From Table 2, as compared with the control group $(3.40 \pm 0.19 \mathrm{~g} / \mathrm{dl})$ there was a significant $(\mathrm{P}<0.05)$ decrease in the total protein $(\mathrm{g} / \mathrm{dl})$ in the liver homogenate of rats exposed to intoxicating dose of MSG, group D $(2.64 \pm 0.09 \mathrm{~g} / \mathrm{dl},-22.35 \%)$ and in those exposed to AL overdose together with intoxicating dose of MSG, group F $(2.81 \pm 0.14 \mathrm{~g} / \mathrm{dl},-17.35 \%)$, but an increase $(\mathrm{P}<0.05)$ in that of rats exposed to AL therapeutic dose, group B $(4.10 \pm 0.05 \mathrm{~g} / \mathrm{dl},+20.59 \%)$ whereas there was a non-significant $(\mathrm{P}>0.05)$ decrease in the rats exposed to AL overdose, group C $(3.03 \pm 0.27 \mathrm{~g} / \mathrm{dl},-10.88 \%)$ and in those exposed to AL therapeutic dose together with intoxicating dose of MSG, group E (3.04 $\pm 0.23 \mathrm{~g} / \mathrm{dl},-10.59 \%)$.

Table 2: Total protein concentration $(\mathrm{g} / \mathrm{dl})$ in the liver homogenate of normal and monosodium glutamateintoxicated rats co-treated with artemether-lumefantrine

\begin{tabular}{|c|c|c|c|}
\hline Group & Total protein(g/dl) & $\begin{array}{c}\text { Changes relative to the } \\
\text { control (\%) }\end{array}$ & $\begin{array}{c}\text { Changes relative to the } \\
\text { MSG group }(\%)\end{array}$ \\
\hline A: Control (feed + water only) & $3.40 \pm 0.19$ & 0.00 & +28.79 \\
\hline B: AL therapeutic dose & $4.10 \pm 0.05$ & +20.59 & +55.30 \\
\hline C: AL overdose & $3.03 \pm 0.27$ & -10.88 & +14.77 \\
\hline D: MSG (8000mgkg ${ }^{-1}$ bwt) & $2.64 \pm 0.09$ & -22.35 & 0.00 \\
\hline E: AL therapeutic dose + MSG & $3.04 \pm 0.05$ & -10.59 & +15.15 \\
\hline F: AL overdose + MSG & $2.81 \pm 0.14$ & -17.35 & +6.44 \\
\hline
\end{tabular}

Values are mean \pm SEM for $n=5 .+$ denotes higher by; - denotes lower by. Difference considered statistically significant at $p<0.05$ and a relative change of ten (10) per cent and above [42].

As shown in Table 3, the malondialdehyde concentration $(\mathrm{mg} / \mathrm{ml})$ in the serum of rats exposed to AL therapeutic dose, group B $(0.55 \pm 0.08 \mathrm{mg} / \mathrm{ml},+30.95 \%)$ was higher $(\mathrm{P}<0.05)$ compared to the control group $(0.42 \pm 0.02 \mathrm{mg} / \mathrm{ml})$. The MDA concentration in the serum of rats exposed to AL overdose, group C $(0.47 \pm 0.03 \mathrm{mg} / \mathrm{ml})$, intoxicating dose of MSG, group D $(0.47 \pm 0.01 \mathrm{mg} / \mathrm{ml})$ and AL overdose together with intoxicating dose of MSG, group F $(0.45 \pm 0.02 \mathrm{mg} / \mathrm{ml})$ was higher but not significant $(\mathrm{P}>0.05)$ as compared to the control rats. However, the MDA concentration in the serum of rats exposed to AL therapeutic dose together with intoxicating dose of MSG, group E $(0.42 \pm 0.02 \mathrm{mg} / \mathrm{ml})$ was similar to that of the control.

Table 3: Malondialdehyde concentration $(\mathrm{mg} / \mathrm{ml})$ in the serum of normal and monosodium glutamateintoxicated rats co-treated with artemether-lumefantrine

\begin{tabular}{|c|c|c|c|}
\hline Group & $\operatorname{MDA}(\mathrm{mg} / \mathrm{ml})$ & $\begin{array}{c}\text { Changes relative to the } \\
\text { control }(\%)\end{array}$ & $\begin{array}{c}\text { Changes relative to the } \\
\text { MSG group (\%) }\end{array}$ \\
\hline A: Control (feed + water only) & $0.42 \pm 0.02$ & 0.00 & -10.64 \\
\hline B: AL therapeutic dose & $0.55 \pm 0.08$ & +30.95 & +17.02 \\
\hline C: AL overdose & $0.47 \pm 0.03$ & +11.90 & 0.00 \\
\hline D: MSG (8000mgkg-1 bwt) & $0.47 \pm 0.01$ & +11.90 & 0.00 \\
\hline E: AL therapeutic dose + MSG & $0.42 \pm 0.02$ & 0.00 & -10.64 \\
\hline F: AL overdose + MSG & $0.45 \pm 0.02$ & +7.14 & -4.26 \\
\hline
\end{tabular}

Values are mean \pm SEM for $n=5 .+$ denotes higher by; - denotes lower by. Difference considered statistically significant at $p<0.05$ and $a$ relative change of ten (10) per cent and above [42].

The MDA concentration in the liver homogenate of rats exposed to AL therapeutic dose, group B $(0.62 \pm 0.05 \mathrm{mg} / \mathrm{ml})$ and to intoxicating dose of MSG, group D $(0.63 \pm 0.02 \mathrm{mg} / \mathrm{ml})$ was higher $(\mathrm{P}<0.05)$ than that of the control group $(0.52 \pm 0.05 \mathrm{mg} / \mathrm{ml})$. However, the MDA concentration in the rats exposed 
Egbuonu et al., Adv.J. Grad. Res.; Vol. 7, Issue 1, pp: 70-79, January 2020

to AL overdose together with intoxicating dose of MSG, group F $(0.45 \pm 0.04 \mathrm{mg} / \mathrm{ml})$ was lower $(\mathrm{P}<0.05)$ than that of control and other groups (Table 4).

Table 4: Malondialdehyde concentration $(\mathrm{mg} / \mathrm{ml})$ in the liver homogenate of normal and monosodium glutamate-intoxicated rats co-treated with artemether-lumefantrine

\begin{tabular}{|c|c|c|c|}
\hline Group & MDA (mg/ml) & $\begin{array}{c}\text { Changes relative to the } \\
\text { control }(\%)\end{array}$ & $\begin{array}{c}\text { Changes relative to the } \\
\text { MSG group (\%) }\end{array}$ \\
\hline A: Control (feed + water only) & $0.52 \pm 0.05$ & 0.00 & -17.46 \\
\hline B: AL therapeutic dose & $0.52 \pm 0.05$ & 0.00 & -17.46 \\
\hline C: AL overdose & $0.51 \pm 0.03$ & -1.92 & -19.05 \\
\hline D: MSG (8000mgkg-1 bwt) & $0.63 \pm 0.02$ & +21.15 & 0.00 \\
\hline $\begin{array}{c}\text { E: AL therapeutic dose }+ \\
\text { MSG }\end{array}$ & $0.52 \pm 0.04$ & 0.00 & -17.46 \\
\hline F: AL overdose + MSG & $0.45 \pm 0.04$ & -13.46 & -28.57 \\
\hline
\end{tabular}

Values are mean \pm SEM for $n=5$. + denotes higher by; - denotes lower by. Difference considered statistically significant at $p<0.05$ and a relative change of ten (10) per cent and above [42].

From Table 5, albumin concentration in the serum of rats exposed to intoxicating dose of MSG, group D $(2.59 \pm 0.13 \mathrm{~g} / \mathrm{dl}), A L$ overdose together with intoxicating dose of MSG, group F $(3.24 \pm 0.12 \mathrm{~g} / \mathrm{dl})$, and AL therapeutic dose together with intoxicating dose of MSG, group E $(2.31 \pm 0.09 \mathrm{~g} / \mathrm{dl})$ was higher $(\mathrm{P}<0.05)$ than that of the control $(2.02 \pm 0.04 \mathrm{~g} / \mathrm{dl})$. The albumin concentration in the serum of rats exposed to AL therapeutic dose, group B $(1.95 \pm 0.10 \mathrm{~g} / \mathrm{dl})$ was lower $(\mathrm{P}>0.05)$ while that for the rats exposed to AL overdose, group C $(2.09 \pm 0.42 \mathrm{~g} / \mathrm{dl})$ was higher $(\mathrm{P}>0.05)$ compared to the control $(2.02 \pm 0.04 \mathrm{~g} / \mathrm{dl})$.

Table 5: Albumin concentration ( $\mathrm{g} / \mathrm{dl}$ ) in the serum of normal and monosodium glutamate-intoxicated rats cotreated with artemether-lumefantrine

\begin{tabular}{|c|c|c|c|}
\hline Group & Albumin (g/dl) & $\begin{array}{c}\text { Changes relative to the } \\
\text { control }(\%)\end{array}$ & $\begin{array}{c}\text { Changes relative to the } \\
\text { MSG group (\%) }\end{array}$ \\
\hline A: Control (feed + water only) & $2.02 \pm 0.04$ & 0.00 & -22.01 \\
\hline B: AL therapeutic dose & $1.95 \pm 011$ & -3.47 & -24.71 \\
\hline C: AL overdose & $2.09 \pm 0.04$ & +3.47 & -19.31 \\
\hline D: MSG (8000mgkg ${ }^{-1}$ bwt) & $2.59 \pm 0.13$ & +28.22 & -10.81 \\
\hline E: AL therapeutic dose + MSG & $2.31 \pm 0.09$ & +14.36 & +25.10 \\
\hline F: AL overdose + MSG & $3.24 \pm 0.12$ & +60.40 & \\
\hline
\end{tabular}

Values are mean \pm SEM for $n=5$. + denotes higher by; - denotes lower by. Difference considered statistically significant at $p<0.05$ and a relative change of ten (10) per cent and above [42].

Table 6: Albumin concentration $(\mathrm{g} / \mathrm{dl})$ in the liver homogenate of normal and monosodium glutamateintoxicated rats co-treated with artemether-lumefantrine

\begin{tabular}{|c|c|c|c|}
\hline Group & Albumin (g/dl) & $\begin{array}{c}\text { Changes relative to the } \\
\text { control }(\%)\end{array}$ & $\begin{array}{c}\text { Changes relative to the } \\
\text { MSG group }(\%)\end{array}$ \\
\hline A: Control (feed + water only) & $1.36 \pm 0.12$ & 0.00 & +16.24 \\
\hline B: AL therapeutic dose & $1.19 \pm 0.05$ & -12.50 & +1.71 \\
\hline C: AL overdose & $1.37 \pm 0.05$ & +0.74 & 0.00 \\
\hline D: MSG (8000mgkg ${ }^{-1}$ bwt) & $1.17 \pm 0.06$ & -13.97 & +2.56 \\
\hline E: AL therapeutic dose + MSG & $1.20 \pm 0.04$ & -11.76 & +14.53 \\
\hline F: AL overdose + MSG & $1.34 \pm 0.05$ & -1.47 & \\
\hline
\end{tabular}

Values are mean \pm SEM for $n=5$. + denotes higher by; - denotes lower by. Difference considered statistically significant at $p<0.05$ and a relative change of ten (10) per cent and above [42].

As depicted in Table 6 , the albumin concentration in the liver homogenate of rats exposed to intoxicating concentration of MSG, group D $(1.17 \pm 0.06 \mathrm{~g} / \mathrm{dl})$, AL therapeutic dose, group B $(1.19 \pm 0.04 \mathrm{~g} / \mathrm{dl})$ and AL therapeutic dose together with intoxicating dose of MSG, group E $(1.20 \pm 0.03 \mathrm{~g} / \mathrm{dl})$ was lower $(\mathrm{P}<0.05)$ than that of rats in the control $(1.36 \pm 0.12 \mathrm{~g} / \mathrm{dl})$. However, the albumin concentration in the liver homogenate of rats exposed to AL overdose, group $\mathrm{C}(1.37 \pm 0.04 \mathrm{~g} / \mathrm{dl})$ was higher $(\mathrm{P}>0.05)$ but lower 
Monosodium Glutamate Plus Artemether-lumefantrine Overdose Altered Malondialdebyde, Total Protein and Albumin Concentration in Rats

$(\mathrm{P}>0.05)$ in the rats exposed to AL overdose together with intoxicating dose of MSG $(1.34 \pm 0.05 \mathrm{~g} / \mathrm{dl})$ compared to the control $(1.36 \pm 0.12 \mathrm{~g} / \mathrm{dl})$.

The result as shown on Table 7 revealed that in the serum of the rats, the Total protein : Albumin ratio was the least while the Albumin : total protein ratio was the highest, respectively in the rats exposed to MSG (1.44 (0.70); representing a decrease by 37.39 and increase by 62.79$)$ followed by that of rats exposed to AL overdose + MSG (1.45(0.69); 36.96(60.47)) and AL overdose (1.59(0.63); 30.87(46.51)) when compared with the control.

Table 7: Total protein: Albumin (total protein: Albumin) ratio in the serum of normal and monosodium glutamate-intoxicated rats co-treated with artemether-lumefantrine

\begin{tabular}{|c|c|c|c|}
\hline Group & $\begin{array}{c}\text { Total protein:Albumin } \\
\text { (Albumin: total protein) }\end{array}$ & $\begin{array}{c}\text { Changes relative to } \\
\text { the control } \%)\end{array}$ & $\begin{array}{c}\text { Changes relative to the } \\
\text { MSG group }(\%)\end{array}$ \\
\hline $\begin{array}{c}\text { A: } \text { Control (feed }+ \text { water } \\
\text { only) }\end{array}$ & $2.30(0.43)$ & $0.00(0.00)$ & $+59.72(-38.57)$ \\
\hline B: AL therapeutic dose & $1.86(0.54)$ & $-19.13(+25.58)$ & $+29.17(-22.86)$ \\
\hline C: AL overdose & $1.59(0.63)$ & $-30.87(+46.51)$ & $+10.42(-10.00)$ \\
\hline$D:$ MSG (8000mgkg $\left.{ }^{-1} b w t\right)$ & $1.44(0.70)$ & $-37.39(+62.79)$ & $0.00(0.00)$ \\
\hline $\begin{array}{c}E: \text { AL therapeutic dose } \\
\text { MSG }\end{array}$ & $1.86(0.54)$ & $-19.13(+25.58)$ & $+29.17(-22 . .86)$ \\
\hline F: AL overdose $+M S G$ & $1.45(0.69)$ & $-36.96(+60.47)$ & $+0.69(-1.43)$ \\
\hline
\end{tabular}

Values are inverse (and converse) ratios of parameters in this study; + denotes higher by; - denotes lower by. Difference considered statistically significant for relative change value of ten (10) per cent and above [42].

The result as shown on Table 8 revealed that in the liver homogenate of the rats, the Total protein : Albumin ratio decreased the most while the Albumin : total protein ratio increased the most, respectively in the rats exposed to AL overdose + MSG (-16.00(20.00)) followed by that of rats exposed to AL overdose (11.60(12.50) and MSG (-9.60(10.00) when compared with the control.

Table 8: Total protein: Albumin (Albumin: total protein) ratio in the liver homogenate of normal and monosodium glutamate-intoxicated rats co-treated with artemether-lumefantrine

\begin{tabular}{|c|c|c|c|}
\hline Group & $\begin{array}{c}\text { Total protein: Albumin } \\
\text { (Albumin: total protein) }\end{array}$ & $\begin{array}{c}\text { Changes relative to } \\
\text { the control }(\%)\end{array}$ & $\begin{array}{c}\text { Changes relative to the } \\
\text { MSG group }(\%)\end{array}$ \\
\hline A: Control (feed + water only) & $2.50(0.40)$ & $0.00(0.00)$ & $+10.62(-9.09)$ \\
\hline$B:$ AL therapeutic dose & $3.45(0.29)$ & $+38.00(-27.50)$ & $+52.65(-40.91)$ \\
\hline C: AL overdose & $2.21(0.45)$ & $-11.60(+12.50)$ & $-2.21(+2.27)$ \\
\hline D: MSG $\left(\right.$ 8000mgkg ${ }^{-1}$ bwt) & $2.26(0.44)$ & $-9.60(+10.00)$ & $0.00(0.00)$ \\
\hline$E:$ AL therapeutic dose $+M S G$ & $2.53(0.39)$ & $+1.20(-2.50)$ & $+11.95(-11.36)$ \\
\hline$F:$ AL overdose $+M S G$ & $2.10(0.48)$ & $-16.00(+20.00)$ & $-7.08(+9.09)$ \\
\hline
\end{tabular}

Values are inverse (and converse) ratios of parameters in this study; + denotes higher by; - denotes lower by. Difference considered statistically significant for relative change value of ten (10) per cent and above [42].

\section{Discussion}

MSG could alter energy balance in animals with possible health consequences (44) while artemetherlumefantrine (AL) and monosodium glutamate (MSG), respectively mediated oxidative stress which is fundamental in diseased conditions [25, 26]. Recently, normal rats exposed to overdose of AL together with MSG had compromised liver morphology and antioxidant capacity [28]. Altered liver bio-function could be detrimental to balanced physio-function. In particular, malondialdehyde, could react on cellular and tissue proteins to form adduct resulting to the alteration of protein function and attendant cellular responses [29], warranting this study. The result showed markedly lowered $(\mathrm{P}<0.05)$ total protein concentration $(\mathrm{g} / \mathrm{dL})$ in the liver homogenate of rats exposed to MSG (group D) or MSG plus AL overdose (group F), compared to other groups. The observation could be attributed to compromised liver integrity or function resulting to or from adverse influence on protein metabolism cum function in the group of rats [45]. Proteins 
are essentially produced in and secreted by hepatocytes (liver cells) [46] and lowered protein concentration could reflect impaired liver integrity following enhanced adduct formation with malondialdehyde [47]. Thus, compromised protein synthesis or enhanced protein catabolism, including up-regulated proteinmalondialdehyde adduct formation following possibly compromised liver integrity and bio-functions could result to reduced protein concentration as observed in the present study. The observation was significant and marked in the liver homogenate of rats exposed to MSG either alone (group D) or together with an overdose of AL (group F) (Table 2).This, in apparent support of earlier study [28], underscored a marked adverse influence of concomitant exposure of MSG and overdose of AL on the liver integrity and livermediated protein metabolism and bio-functions, including possibly enhanced protein-malondialdehyde adduct formation, in non-malarial-infested rats.

Similarly, the MDA concentration $(\mathrm{mg} / \mathrm{ml})$ in the liver homogenate of rats exposed to overdose of AL together with MSG $(0.45 \pm 0.04 \mathrm{mg} / \mathrm{ml})$ was lower $(\mathrm{P}<0.05)$ than that of the control and other groups, seemingly supporting the inferred possibly enhanced protein-malondialdehyde adduct formation as likely mechanism leading to the observed reduction in protein concentration in the studied samples. In particular, the observation and the bio-consequence could be overriding in the liver of rats concomitantly exposed to AL overdose and MSG. Prevailing MDA concentration in biologic sample could be diagnostic [48]. Cellular and tissue proteins-related malondialdehyde adduct formation could result in protein dysfunction and attendant alteration in cellular responses $[29,49]$. Thus, reduction in malondialdehyde concentration could be as a consequence of compromised antioxidant status of the rats [28] and its (MDA) possibly enhanced reaction with cellular and tissue proteins which probably explained the co-consequent reduction in total protein concentration of the rats as observed in this study. The reduction in MDA concentration seemingly confirms earlier reports of significant decrease in the antioxidants parameters due to an induction of oxidative stress by monosodium glutamate [26,28], which overwhelmed the rats antioxidants capacity resulting to the depletion [50] as observed. MSG-related lipid peroxidation on the liver leading to liver damage has been reported [49]. Thus, the apparent interactive effect of overdose of AL together with overdose of MSG could be synergistic and detrimental on the MDA concentration and associated biofunctions in, notably, the liver of rats. However, the albumin concentration $(\mathrm{mg} / \mathrm{ml})$ in rats exposed to MSG alone $(2.59 \pm 0.13 \mathrm{~g} / \mathrm{dl})$ or to an overdose of AL together with MSG $(3.24 \pm 0.12 \mathrm{~g} / \mathrm{dl})$, compared to the control $(2.02 \pm 0.04 \mathrm{~g} / \mathrm{dl})$, was higher $(\mathrm{P}<0.05)$ in the serum, indicating apparent diminution in albumin elimination due perhaps to renal excretory dysfunctions [38]. On the other hand, the albumin concentration in the liver homogenate of rats exposed to MSG $(1.17 \pm 0.06 \mathrm{~g} / \mathrm{dl})$, therapeutic dose of AL $(1.19 \pm 0.04 \mathrm{~g} / \mathrm{dl})$ and therapeutic dose of AL together with MSG $(1.20 \pm 0.03 \mathrm{~g} / \mathrm{dl})$ was lower $(\mathrm{P}<0.05)$ than that of rats in the control $(1.36 \pm 0.12 \mathrm{~g} / \mathrm{dl})$, indicating apparently enhanced free radical generation-related adverse response in the rats [50].Albumin is essentially prominent binding cum transport protein, and low concentration could be due to its antioxidant activity [51] aside protein loss in nephrotic syndrome as well as decreased synthesis and negative fluid imbalance as in chronic liver impairment [52].

Appropriate ratios of the studied bio-indicators could be prognostic[53].In the serum and liver homogenate of the rats, the total protein : albumin ratio was lower while the albumin : total protein ratio was higher, respectively in the rats exposed to MSG, Overdose of AL + MSG or overdose of AL when compared with the control. The observation could be a pointer to hitherto unknown underlying pathology as recently low albumin/globulin ratio was significantly associated with poor overall survival in various cancers [54] while a low albumin to globulin ratio was a prognostic marker for poor survival in cervical cancer patients [55]. Generally, the non-significant $(\mathrm{P}>0.05)$ and inconsistent responses in some groups, is not surprising. At therapeutic dose, AL was reportedly well-tolerated with negligible side response [56], while the intoxicating dose of MSG at short exposure duration as in this study (7 days) may not have caused observable toxicity in the rats' samples. The inconsistent result in the serum and liver homogenate samples could be attributed to the long circulatory half-life of albumin [57] and commonly known high volatility of lipid peroxidation products, including MDA vis a vis the possibly higher antioxidant activity in the liver implying unequal utilization hence unequal balance of the determined bio-indicators in the two samples as observed. 
Furthermore, induction of oxidative stress leading to liver tissue damage may occur despite apparent beneficial or insignificant alteration in antioxidant markers [24]. Howbeit, these (non-significant and inconsistent observations) are significant limitation of the present study. Further studies aimed at eliminating the noted limitations could provide useful insight on the studied area, hence are warranted.

\section{Conclusion}

Thus, the apparent MSG plus AL overdose-induced adverse influence on the studied parameters and samples of non-malarial infested rats could be via compromised liver-mediated protein metabolism capacity and bio-functions following possibly enhanced protein-malondialdehyde adduct formation in the rats.

\section{Declarations}

\subsection{Study Limitations}

The study was limited to changes in malondialdehyde, total protein and albumin concentration in the serum and liver homogenate of monosodium glutamate-intoxicated rats co-treated with artemether-lumefantrine for only seven consecutive days exposure.

\subsection{Ethical Approval}

The authors declare that ethical approval for the use of animals was sought and obtained from the College of Natural Sciences, Michael Okpara University of Agriculture Ethical Committee (CREC/003/19). And, the animals were handled humanely in line with the ethical requirements.

\subsection{Competing Interests}

The authors declared that no conflict of interest exists in the publication of this work.

\section{How to Cite this Article:}

A. C. Egbuonu, "Monosodium Glutamate Plus Artemether-lumefantrine Overdose Altered Malondialdehyde, Total Protein and Albumin Concentration in Rats", Adv. J. Grad. Res., vol. 7, no. 1, pp. 70-79, Dec. 2019. doi:10.21467/ajgr.7.1.70-79

\section{References}

[1] A. A. Amal, S. M. Marwa, and A. A. Mona, Effect of honey on monosodium glutamate induced nephrotoxicity. J Am Sci, vol. 8, Issue 1, pp. 146-56, 2012.

[2] H. O. Akanya, S. Peter, and I. F. Ossamulu, Evaluation of the changes in some liver function and haematological parameters in monosodium glutamate fed rats. Intl J Biochem Res and Rev, vol. 6, Issue 3, pp. 113-20, 2015.

[3] A. J. Ajibade, P. B. Fakunle, and A. A. Mene, et al., Some cardioprotective effects of aqueous extract of ginger against monosodium glutamate induced toxicity in the heart of male Wistar rats. Intl J of Recent Sci Res, vol. 4, Issue 6, pp. 972-78, 2013.

[4] M. E. Afaf, and Z. A. E. Somaia, Protective role of ginkgo biloba on monosodium glutamate: Induced liver and kidney toxicity in rats. Res J of Pharmaceut, Biol and Chem Sci, vol. 6, Issue 1, pp. 1433-41, 2015.

[5] K. Niaz, E. Zaplatic, and J. Spoor, (2018). Extensive use of monosodium glutamate: A threat to public health? Exptl and Clin Sci J, EXCLI J, vol. 17. pp. 273-78. 2018.

[6] A. A. Madiha, A. A. Abeer, and F. A. Ellah, et al., The possible ameliorative effect of propolis in rats liver treated with monosodium glutamate. Natural Science, vol. 10, Issue 2012, pp. 209-19, 2012.

[7] T. S. Mariyamma, K. S. Sujatha, and S. George, Protective effect of Piper longumLinn on monosodium glutamate-induced oxidative stress in rats.Indian J ExpBiol, vol. 47, pp. 186-92, 2009.

[8] O. O. Okwudiri, C. S. Alisi, and A. P. Ihetuge, Monosodium glutamate induces oxidative stress and affects glucose metabolism in the kidney of rats. Intl J Biochem Res \& Rev, vol. 2, pp. 1-11, 2012.

[9] A. C. C. Egbuonu, C. A. Ezeokonkwo, and P. M. Ejikeme, et al. Some biochemical effects of sub-acute oral administration of Larginine on monosodium glutamate fed Wistar albino rats 2: Serum alkaline phosphatase, total acid phosphatase and aspartate aminotransferase activities.Asian J Biochem, vol. 5, Issue 2, pp. 89-95, 2010.

[10] A. C. C. Egbuonu, O. Obidoa, and C. A. Ezeokonkwo, et al. Some biochemical effects of subacute oral administration of L-arginine on monosodium glutamate fed Wistar albino rats 1: body weight changes, serum cholesterol, creatinine and sodium ion concentrations. Toxicol and Environ Chem, vol. 92, Issue 7, pp. 1331-37, 2010.

[11] A. C. C. Egbuonu, L. U. S. Ezeanyika, P. M. Ejikeme, and O. Obidoa, Histomorphologic alterations in the liver of male Wistar rats treated with 1-arginine glutamate and monosodium glutamate. Res. J. Environ. Toxicol, vol. 4, Issue 4, pp. 205-13, 2010.

[12] A. C. C. Egbuonu, P. M. Ejikeme, and N.L. Obasi, Monosodium glutamate: Potentials at inducing prostate pathologies in male Wistar rats. Afr J Biotechnol, vol. 9, Issue 36, pp.5950-54, 2010. 
[13] K. Chandra, S. S. Ali, and M. Abid et al. Protection against FCA induced oxidative stress induced DNA damage as a model of arthritis and in vitro antiarthritic potential of Costusspeciosus rhizome extract. Intl J Pharmacognosy and Phytochem Res, vol. 7, Issue 2, pp. 383-89, 2015.

[14] P.D. S. Ventura, C. P. F. Carvalho, and N. M. T. Barros, et al. Malaria infection promotes a selective expression of kinin receptors in murine liver. Malar J, vol.18, Issue 213, pp. 1-10, 2019.

[15] O. Hwang, Role of oxidative stress in Parkinson's disease.ExpNeurobiol, vol. 22, Issue 1, pp. 11-17, 2013.

[16] C. Roma-Mateo, C. Aguado, G. J. L. Garcia et al., Increased oxidative stress and impaired antioxidant response in lafora disease. Molecular Neurobiol, vol. 51, Issue 3, pp. 932-46, 2015.

[17] P. Byakika-kibwika, M. Lamorde, H. Mayanja-Kizza, S. Khoo, C. Merry, and J. P. van-Geertruyden, Artemether-Lumefantrine Combination Therapy for Treatment of Uncomplicated Malaria: The Potential for Complex Interactions with Antiretroviral Drugs in HIV-Infected Individuals. Malaria Res and Treatment, vol. 2011, pp. 1-5, 2011.

[18]. C. A. Otuechere, G. Edewor, and O. E. Kale, et al., Sub-acute therapeutic dosing of artemether-lumefantrine and artesunateamodiaquine combination preserves plasma cholesterol, renal antioxidant status, and organ weights in rats. Malaria Res and Treatment, vol. 2012, Issue 2012, pp. 1-5, 2012.

[19] R.J. Little, A. A. Pestano, and Z. Parra, Modeling of peroxide activation in artemisinin derivatives by serial docking. J of Molecular Modeling, vol. 15, pp.847-58, 2009.

[20] World Health Organization (WHO), World malaria report 2014, pp. 1-142, 2014.

[21] O. A. Daikwo, M. U. Kawu, and R. A. Magaji, et al., Effect of prolonged administration of artemether-lumefantrine on testicular biomarkers of oxidative stress: Ameliorative effect of vitamin E. Basic Sciences of Medicine, vol. 7, Issue 1, pp. 1-6, 2018.

[22] S. Abdel-misih, and M. Bloomston, Liver anatomy.Surgical Clinics of North America, vol. 90, Issue 4, pp. 643-53, 2010.

[23] A. C. C. Egbuonu, A. E. Ogbu, and L. U. S. Ezeanyika, Dose-related influence of esculetin (6,7-dihydroxy-coumarin) on some liver and prostate function markers of male Wistar rats. J BiolSci, vol. 12, Issue 4, pp. 253-57, 2012.

[24] M. Zebrowska-Gamdzyk, M. Maciejczyk, and A. Zalewska, et al. Whey protein concentrate WPC-80 intensifies glycoconjugate catabolism and induces oxidative stress in the liver of rats. Nutrients, vol.10, Issue 1178. pp. 1-16. 2018.

[25] A. C. C. Egbuonu, and G. E. Ejike, Effect of pulverized Mangiferaindica(mango) seed kernel on monosodium glutamate-intoxicated rats' serum antioxidant capacity, brain function and histology. EC Pharmacol. Toxicol, vol. 4, Issue 6, pp. 228-43, 2017.

[26] C. Lopez-Alarcon, and A. Denicola, Evaluating the antioxidant capacity of natural products: A review on chemical and cellular-based assays. Analytical ChimicaActa, vol.763, pp. 1-10, 2013.

[27] O. M. Akanbi, A. B. Odaibo, and K. A. Afolabi, et al., Effect of self-medication with antimalarial drugs on malaria infection in pregnant women in South-Western Nigeria. Medical Principles and Practice, vol. 14, Issue 1, pp. 6-9, 2005.

[28] E. Obi, and A. C. C. Egbuonu, Changes in the liver histomorphology, catalase and glutathione peroxidase activity in the serum and liver homogenate of normal and monosodium glutamate-intoxicated rats co-treated with artemether-lumefantrine. Int J MolBiol Open Access, vol. 4, Issue 2, pp. 67-73, 2019.

[29] M. M. Gaschler, and B. R. Stockwell, Lipid peroxidation in cell death.Bioch and Biophys Res Commun, vol. 482, Issue 3, pp. 419$25,2017$.

[30] A. A. Omari, C. Gamble, and P. Garner, Artemether-lumefantrine (four-dose regimen) for treating uncomplicated falciparum malaria. Cochrane Database of Systematic Reviews, vol. 2, pp. CD005965, 2006.

[31] A. C. C. Egbuonu, and S. O. Oriji, Pulverized Mangiferaindica(mango) seed kernel mitigated monosodium glutamate-intoxicated rats' kidney histology and bio-functions. J Nutri Health and FdSci, vol. 5, Issue 2, pp. 1-7, 2017.

[32] U. O. Mbah, and A. C. C. Egbuonu, Ethanolic extract of SolanummelongenaLinn fruit mitigated monosodium glutamate-induced oxidative stress. Intl J Biochem Res \& Rev, vol. 18, Issue 2, pp. 1-8, 2017.

[33] U. O. Mbah, and A. C. C. Egbuonu, Ameliorative potentials of egg plant (SolanummelongenaLinn) fruit ethanolic extract on monosodium glutamate intoxicated rats lipid profile, haematology and heart histology. Intl JBiochem Res \& Rev, vol. 18, Issue 3, pp. $1-10,2017$.

[34] A. C. C. Egbuonu, and G. A. Ekwuribe, Pulverized Mangiferaindica(mango) seed-kernel modulated serum lipid profile in monosodium glutamate-challenged rats. J ApplBiotechnol, vol. 5, Issue 2, pp. 20-35, 2017.

[35]. B. Wallin, B. Rosengren, H. G. Shertzer and G. Cameyo, Lipoprotein oxidation and measurement of TBARS formation in a single microtiter plate: Its use for evaluation of antioxidants. Anal Biochem, vol. 208, pp. 10-15, 1993.

[36] A. C. C. Egbuonu, and L. U. S. Ezeanyika L.U.S, Effect of L-arginine on selected markers of metabolic syndrome related to oxidative stress, glucose metabolism and nitric oxide synthesis in female Wistar albino rats. Intl Res $\mathbf{J}$ of Biochem and Bioinformatics, vol. 2, issue 8, pp. 186-92, 2012.

[37] B. T. Doumas, W. A. Watson, and H. G. Biggs, Albumin standard and the measurement of serum albumin with bromcresol green. ClinChimActa, vol. 3, Issue 1, pp. 87-96, 1971.

[38] A. C. C. Egbuonu, and L. U. S. Ezeanyika, L-arginine exposure improves renal function markers of metabolic syndrome in female rats. Am J of Bioch and MolBiol, vol. 3, Issue 1, pp. 50-60, 2013.

[39] A. C. C. Egbuonu, Effect of some antihypertensives on the serum bilirubin concentration of male Wistar rats. J of Pharmacy and Pharmacol Res, vol. 1, Issue 1, pp. 009-12, 2010.

[40] A. C. C. Egbuonu, D. C. Nzewi, and O. N. C. Egbuonu, Effect of soaking prior to oven-drying on some nutrient and anti-nutrient properties of bitter yam (Dioscoreadumetorum). J NutrFdSci, vol. 4, Issue 280, pp. 1-4,2014.

[41] A. C. C. Egbuonu, D. C. Nzewi, and O. N. C. Egbuonu, Functional properties of bitter yam (Dioscoreadumetorum) as influenced by soaking prior to oven-drying. Am J FdTechnol, vol. 9, Issue 2, pp. 97-03, 2014.

[42] A. C. C. Egbuonu, Effect of ethanolic extract of pulverized Mangiferaindica (mango) seed kernel on some hematological parameters in normal and monosodium glutamate-intoxicated rats. Intl J of Res in Environ Sci, vol. 4, Issue 1, pp. 47-55, 2018.

[43] A. C. C. Egbuonu, C. I. Opara, D. Akachukwu, and U. B. Onyedikachi, Effect of ethanolic extract of avocado pear (Perseaamericana) seed on normal and monosodium glutamate-compromised rats' hepatic histo-morphology and serum bio-functional parameters. Res J Environ Sci, vol. 12, Issue 2, pp. 53-62, 2018. 
Monosodium Glutamate Plus Artemether-lumefantrine Overdose Altered Malondialdebyde, Total Protein and Albumin Concentration in Rats

[44] T. R. Araujo, I. N. Freitas, J. F. Vettorazzi, T, M. Batista, and J. C. Santos-Silva, et al. Benefits of L-alanine or L-arginine supplementation against adiposity and glucose intolerance in monosodium glutamate-induced obesity. Eur J Nutr, vol. 56, Issue 6, pp. 2069-80, 2017.

[45] M. Andjelkovic, A. B. Djordjevic, E. Antonijevic, and B. Antonijevic, et al. Toxic effect of acute cadmium and lead exposure in rat blood, liver, and kidney. Int. J. Environ. Res. Public Health, 2019, vol. 16, Issue 274; pp. 1-21.

[46] A. Treyer, and A. Musch, Hepatocyte polarity.Comprehensive Physiol, vol. 3, Issue 1, pp.243-87, 2013.

[47] S. Pizzimenti, E. Ciamporcero, M. Daga, P. Pettazzoni, and et al., Interaction of aldehydes derived from lipid peroxidation and membrane proteins. Frontierof Physiol, vol. 4, pp. 242, 2013.

[48] A. C. C. Egbuonu, A. E. Ogbu, I. I. Ijeh, and L. U. S. Ezeanyika, Sub-chronic esculetin (6,7-dihydroxy-coumarin)-induced alteration in some haematological and serum parameters in normal male Wistar rats. Asian J Bioch, vol. 10, Issue 6, pp. 306-11, 2015.

[49] A. Ayala, M. F. Munoz, and S. Arguelles, Lipid Peroxidation: Production, Metabolism, and Signaling Mechanisms of Malondialdehyde and 4-Hydroxy-2-Nonenal. Oxid Med CellLongev, vol. 2014, Issue 2014, pp. 3604-38, 2014.

[50] V. O. Ukwenya, A. S. Tijani, G. A. Sodunke, and J. B. Fakunle, Acute administration of co-artesiane® induces oxidative stress in the testes of adult male Wistar rats. Biosci Rescommun, vol. 22, Issue 5, pp. 259-65, 2010.

[51] D. G. Levitt, and M. D. Levitt, Human serum albumin homeostasis: a new look at the roles of synthesis, catabolism, renal and gastrointestinal excretion, and the clinical value of serum albumin measurements. Intl J of General Medicine, vol. 9, pp. 229-55, 2016.

[52] P. B. Soeters, R. Robert, R. R. Wolfe, and A. Shenkin, Hypoalbuminemia: Pathogenesis and Clinical Significance. J Parenteral and Enteral Nutr, vol.43, Issue 2, pp. 181-93, 2019.

[53] A. C. C. Egbuonu, and L. U. S. Ezeanyika, Effect of L-arginine on some biochemical markers of metabolic syndrome associated with brain function in female Wistar rats. J Applied Sci, vol. 13, Issue 4, pp. 595-01, 2013.

[54] J. Chi, Q. Xie, J. Jia, and X. Liu, et al., Prognostic Value of Albumin/Globulin Ratio in Survival and Lymph Node Metastasis in Patients with Cancer: A Systematic Review and Meta-Analysis. J of Cancer, vol. 9, Issue 13, pp. 2341-48, 2018.

[55] Y. Yoshino, A. Taguchi, T. Shimizuguchi, Y. Nakajima, and et al., A low albumin to globulin ratio with a high serum globulin level is a prognostic marker for poor survival in cervical cancer patients treated with radiation based therapy. Intl J Gynecol Cancer, vol. 29, Issue 1, pp. 17-22, 2019.

[56] C. Falade, M. Makanga, Z. Premji, C. E. Ortmann, and et al., Efficacy and safety of artemether-lumefantrine (Coartem) tablets (sixdose regimen) in African infants and children with acute, uncomplicated falciparum malaria. Transactions of the Royal Society of Tropical Medicine and Hygiene, vol. 99, Issue 6, pp. 459-67, 2005.

[57] S. Darrell, Albumin and its application in drug delivery. Expert Opinion on Drug Delivery, vol. 12, Issue 5, pp. 793-12, 2015.

Publish your books with AIJR publisher-

$\checkmark$ Publish with ISBN and DOI.

$\checkmark$ Publish Thesis/Dissertation as Monograph.

$\checkmark$ Publish Book Monograph.

$\checkmark$ Publish Edited Volume/ Book.

$\checkmark$ Publish Conference Proceedings

$\checkmark \quad$ Retain full copyright of your books.

Submit your manuscript at books.aijr.org
Publish your research article in AIJR journals-

$\checkmark$ Online Submission and Tracking

$\checkmark$ Peer-Reviewed

$\checkmark$ Rapid decision

$\checkmark \quad$ Immediate Publication after acceptance

$\checkmark \quad$ Articles freely available online

$\checkmark \quad$ Retain full copyright of your article.

Submit your article at journals.aijr.in 